\title{
Productive Clerks: White-Collar Productivism and State-Building in Palestine's Jewish Community, 1920-1950*
}

\author{
DAVID DE VRIES
}

SUmmary: Jewish clerks during the Zionist state-building period were intensively engaged in the social construction of productivity, and in turning the latter into a mechanism of social restraint. The clerks' productivism and concem with social utility was manifested in the reproduction of accepted Zionist physiocratic and constructivist notions of productivity, as a strategy in the politics of status; in the modernist transformation of the understanding of productivity to suit their own occupational terminology; in the prescription of the necessary qualities of the productive clerk; and in realization of these discursive campaigns in the practice of labor relations. These manifestations challenge a simplistic approach to the dissemination of the language of productivity as either a one-sided nationalist socialization, or a straightforward managerial strategy of control. Based on primary archival sources of the clerks and their union this paper argues instead that they reflected the intertwining of national attitudes with from-below advancement of group interests.

One of the features accompanying the establishment of the state of Israel in the late 1940s was a "productivity craze". The state's first government (headed by David Ben-Gurion), the General Federation of Labor (Ha-Histadrut Ha-Klalit) and industrialists all joined together in stressing the need to increase productivity and introduce rationalization and efficiency. Related as it was to the anxieties following the Holocaust and the costly 1948 war, and to the burden of immigrants' absorption on Israel's economic structure, this "obsession" spread to various levels of society. The idea of increasing production and labor productivity (Pirion Avoda) mobilized workers and ordinary people to the new cause of building a state through production, of "producing" the conditions necessary to turn

* Earlier versions of this paper were read at the 1996 Annual Conference of the Israel Sociological Association, and at the 1996 European Social Science History Conference, The Netherlands. For their very helpful comments I wish to thank Gideon Kunda, Yehuda Shenhav, Marcel van der Linden and the anonymous reviewers. I am grateful to research assistant Iris Fait, to the archivists and librarians at the Lavon Institute, and to the Faculty of the Social Sciences at Tel Aviv University for its support. Translation of Hebrew titles is in square brackets. 
Israel into a viable economic entity. Managers and workers, economic specialists and technicians were sent to America, France and Switzerland to leam new methods of optimizing production and rationalizing the unstable economy. Experts were brought over to Israel to hand over personally the by now established and well-practised legacies of American and European management science and productivist culture. Other industrializing countries too have experienced such "productivity crazes", though much earlier and with varying characteristics. However, in the Israeli case there was hardly an economic sector untouched by productivism, as state functionaries, entrepreneurs and organized workers were jointly mobilized - by ideological persuasion no less than by collective agreements - to a corporatist venture to assure the endurability of the newly born state entity. Despite initial disappointments of its practical outcome it evolved into a social banner of both employers and employees, a political slogan of both left and right, a widely disseminated national discourse. $^{1}$

Clerks - seemingly a very unlikely stratum to preoccupy itself with quantitative measurement of labor produce - were among the most prominent forces advancing this productivist culture. This puzzling phenomenon was made evident by productivity discourse becoming part and parcel of the daily lives of clerks; particularly unionized office workers working in Zionist national institutions, in the Histadrut, in municipalities and local authorities, as well as in private establishments. It caught a central place in clerical bulletins and newspapers, was repeatedly and intensively discussed in meetings of the Histadrut-affiliated Clerks' Union (Histadrut Ha-Pekidim), and later also in those of the separate Union of State Employees; and turned in the 1950s into an extremely topical issue among the elite and the rank and file of this urban white-collar group. ${ }^{2}$

1 E. Kami, "Tafkjd Dachuf [Urgent Assignment]", Shurot, 101 (May 1950), p. 5; P. Naphtali, "Meshek Milchmati [War Economy]", Shurot, 103 (July 1950), pp. 2-4; 1. Devoskin, "Ratsionalizatsia Be-Avodat Ha-Misrad [Rationalization in Office Work]", Shurot, 113 (May 1951), p. 7. Since 1938 Shurot has been the monthly bulletin of Histadrut Ha-Pekidim (Union of Clerical Employees). For intemational advice see H. Fish, "Raising Productivity in Isracl", International Labour Review, 68, 4-5 (October-November 1953), pp. 3-20. For comparison see A. Carew, Labour Under the Marshall Plan: The Politics of Productivity and the Marketing of Management Science (Detroit, 1987), pp. 136-138; M. Nolan, Visions of Modernity: American Business and the Modernization of Germany (New York, 1994).

2 The Clerks' Union was founded in 1919 on the basis of small local clerical unions already operating from 1913. It became part of the union structure of the Histadrut when the latter was established at the end of 1920 . It was a Jewish organization based on clerks working at Zionist, labor and private capital institutions. Only a few of the clerks who worked in the bureaucracy of the British Mandatory Govermment were Histadrut members. They were represented either by the Union of Railways, Post and Telegraph Workers, or the Union of Government Clerks. The Union of State Employees was set up (despitc opposition from the Histadrut Clerks' Union) in February 1948, in conjunction with the establishment of Isnael. See Be-Mivchan Ha-Ma'aseh: Histadrut Ha-Pekidim, 1945.1948 (In Test of Practice. The Union of Clerks, 1945-1948] (Tel Aviv, 1949); S. Rolbant, Ha-Afirnch 
The fact that in a society, which socially and culturally revered land pioneers, agrarian work, construction and industrial enterprise, national productivity discourse was constructed by white-collar workers in mainly an urban context, was significant for the self-image of Zionism as a modernist venture. Moreover, clerks were influential in the favorable reception of productivism by both urban employers and workers. Through their preoccupation with productivity they played a crucial role in urban cross-class alliances, in themselves vital forces of national integration and statemaking. The clerks' intellectuals and leaders that orchestrated these practices became standard-bearers of a national-bureaucratic ethos, main precursors of rationalization and efficiency, a sort of Taylorite organic ideologues of early Israeli statehood. In a conscious and an interested use of the message and practice of productivity they contributed, apparently more than any other force in Palestine, to the persistence of productivist ideology, far beyond the service sector. Their concern with this ideology enabled the construction of a modern, normative and regimentating concept of productivity; and the turning of productivity culturally and politically instrumental in the cultivation of the Zionist-statist imagination. ${ }^{3}$

How can the clerks' concern with and use of productivity be explained, and what role did clerks play in the latter's social and national construction? These questions, hardly dealt with by either white-collar literature or that of nationalism, are important for the social history of this low white-collar group; and in particular to the ways they experienced the Zionist state-building process. More significantly they bear relevance to the evolution of the reciprocal relations between particular group interests and national collectivity.

On the one hand the emergence and spread of the catchphrases of efficiency and productivity are natural to a state-building society; and, to the socializing efforts of its national elites, closely connected with the service strata, to promote productionism for the sake of social integration and political mobilization. Their visions of modemization, technological pro-

Ha-Demographi, Ha-Kalkali Ve-Ha-Chevrati Shel Tsibur Ha-Pekidim Be-Israel The Demographic, Economic and Social Structure of the Clerks in Israel] (Tel Aviv, 1961).

${ }^{3}$ For Zionist ideology see D. Horowitz and M. Lissak, The Origins of the Israeli Polity: The Political System of the Jewish Community in Palestine under the Mandate (Chicago, 1978), ch. 6. For physical work see H. Hever, Paitanim U-Birionim: Tsmeichat Ha-Shir Ha-Politi Ha-Ivri Be-Eretz-Israel [Poets and Zealots: The Rise of Political Hebrew Poetry in Eretz-Israel] (Jerusalem, 1994), ch. 2. For the modern image see D.J. Penslar, Zionism and Technocracy: The Engineering of Jewish Settlement in Palestine, 1870-1918 (Bloomington, 1991). For the conflictual nature of town society see M. Avizohar, Bir' $i$ Saduk: Idealim Chevrati' im U-Leumi' im Ve-Hishtahfutam Be-Olama Shel Mapai [National and Social Ideals as Reflected in the Party of the Workers of Palestine] (Tel Aviv, 1990), chs 13-16. For Taylorism and labor see M.J. Nadwomy, Scientific Management and the Unions, 1900-1932: A Historical Analysis (Cambridge, MA, 1955), esp. ch. 9; and D. Schecter, Gramsci and the Theory of Industrial Democracy (Aldershot, 1991), pp. 160172. 
gress and national regeneration, and the widespread productivist metaphorization of a new state as undergoing a birth, needing productive capacities and demographic and economic resurgence, are well-known features of national political economies in the modern era. ${ }^{4}$ On the other hand, however, as this case of popular productivist enthusiasm shows, there are particular labor-associated groups elaborating and propagating the banner of productivity; not merely as an expression of their national socialization, but also as a lever to advance their interests, molded and organized by their leaders, in the politics of status and power. Far from being only a part of a collective project, realizing a national ideology or actualizing an inevitable phase during state-building, the clerks demonstrate the importance of the view from below: that is, how the widely-based productivist concern of state-building societies also stems from, and is constructed by, social conflicts in which these occupational groups are involved.

The following discussion deals with the clerks' discursive and nondiscursive political construction of productivity as a manifestation of this intertwining of group-interest, national coalescence and state-building. The focus is on four variations on this theme, each representing a further level of the clerks' productivity discourse. The discussion begins with the clerks' reproduction of accepted notions of productivity as a strategy in the conflictual politics of status. The focus is then shifted to a second, more sophisticated dimension of this strategy, by which the clerks introduced a transformation in the understanding of productivity to suit and advance their own occupational terminology. The third part deals with the corollary of this transformation, namely the prescription of the necessary qualities of the productive clerk. The fourth focuses on the realization of the campaign in the exchange practices of labor relations. The final part contextualizes these four variations of productivism within larger mechanisms of the social politics of early Israeli society. ${ }^{6}$

\section{PRODUCTIVITY REPRODUCED}

The clerks' uses of productivity evolved in the context of their dissonant position in Zionist society. On the one hand they gradually came to hold

4 See C.S. Maier, In Search of Stability: Explorations in Historical Political Economy (Cambridge, 1987). For productivism see also A. Rabinbach, The Human Motor: Energy. Fatigue and the Origins of Modernity (New York, 1990), pp. 272-273.

3 The idea for the article originated from J. Coakley (ed.), The Social Origins of Nationalist Movements: The Contemporary West European Experience (London, 1992); and Y. Shenhav, "Al Ha-Havnaya Ha-Chevratit Shel Pirion Ha-Avoda [On the Social Construction of Labor Productivity]", Shenaton Mishpat Ha-Avoda (1992), pp. 195-212.

- The article does not intend to deal with the maturation of the ideology of productivism in Israel during the 1950s, but only with a segment of its social history. Its wider dissemina. tion requires further research. The article is based on primary archival material of the Clerks' Union and the Histadrut in the Archives of the Labor Movement in the Lavon Institute, Tel Aviv (hereafter LA). Most citations are from the periodical press of the orga- 
key positions in the growing bureaucratic and capitalist structures of the nascent Jewish state. The emergence of a modem Yishuv economy, particularly during the 1930 s and the 1940s, was largely dependent on clerking, both in services, such as insurance and commerce, and in industry. Within the Histadrut the clerks emerged not only as the largest trade union, with 20,400 members in the Clerks' Union at the end of 1948 (15.1 per cent of 135,000 Histadrut total membership and 21.7 per cent of 94,000 union membership); but also as the main force introducing collective agreements in the economy. During the 1940s organized clerks played a crucial role in laying the infrastructure for the new governmental machinery, and in assuring the control of the Labor Movement of governmental functions and local services.

This advancement was, however, contradicted by low social prestige, partly determined by negative social attitudes, as opposed to agriculture and construction, towards the "abstract produce" of the clerks. The origins for what the clerks felt as cultural scorn and social abuse were deeply rooted in the Zionist social and political discourse. Based as it was on the urgent need of Jews for social change, this discourse coupled Zionist nationalism with the need to create a new Jewish working class. This class, the construction of which was possible only in Palestine and on "redeemed" land, was based on agricultural workers, builders and manufacturing labor. Basing themselves on physiocratic, mercantilist and industrialist notions of productive worth, and idealizing material achievements, it has always been common for nation-building societies to endow the agriculturalist, the mason and the industrial worker with the crowning social role. As an immigrant society, originating in the East European social structure where the Jews held intermediate economic positions, the pioneering, agricultural and hand-labor activities were given a formative role in the rhetorical negation of Diaspora society.

Productivization and social normalization (the inversion of the social pyramid) had always been part and parcel of Zionism, let alone as its justification for colonizing Palestine. Labor productivity was not only an essential national issue but also a parameter of social significance and status. In many general and socialist Zionist writings one can find an orchestration of a language that validated or invalidated certain kinds of

nized clerks - Pinkas Le-Inianei Ha-Pekidim [A Booklet on Clerks' Issues], published 1930-1938 (hereafter Pinkas), and Shurot: Pinkas Le-Inianei Ha-Pekidim [Lines: A Booklet on Clerks' Issues], published from 1938 until today (hereafter Shurot).

'The numbers exclude clerks' wives who worked at home and were members of the Histadrut. See Be-Mivchan Ha-Ma'aseh, pp. 13-16. Between 1922 and 1946 the share of clerks in the Jewish population increased from 2.3 per cent to 5.5 per cent. During the same period the share of the organized clerks in the total clerical sector increased from 42.9 per cent to 63.4 per cent. See Ha-Histadrut Ha-Klalit, Sikumim, 13 and 18. See also G. Ofer, The Service Industries in a Developing Economy: The Case of Israel (New York, 1967); Y. Shapiro, Ha-Deomkratia Be-Israel [Democracy in Israel] (Ramat-Gan, 1977). 
work as productive, to the point of placing the so-called unproductive and useless in the lower echelons of the Zionist moral community. The dominant discourse, from which the clerk was alienated, determined the central role of productivity in the derogation of the clerk as social parasite. Marginalization and alienation ensued. ${ }^{8}$

As pre-state Yishuv society endowed one's occupation and type of work with a prominent role, the clerks' focus on productivity as a lever in the politics of status and social prestige was quite understandable. Conceptions of productive and useful clerking had to be "marketed", first and - foremost as a precondition for the wider legitimation of the clerks' role in the Zionist project. As the clerks were strained between an enhanced sense of presence and participation in the bureaucratization and the capitalization of the country on the one hand, and low social and cultural prestige on the other, they strategically addressed the productivist conceptions towards the forces that determined the boundaries between high and low prestige: the employers, who through their labor policies practised a symbolic ordering of useful and non-useful workers; the Labor Movement which following its cultural veneration of agriculture and pioneering left ambiguous the part played by town-dwellers, administrative technocrats and the lower middle class in the Zionist project; and workers at large whose suspicion of the better-off clerks and anxious images of economic future set a wedge between those who had to prove their usefulness and those whose social utility was never doubted. ${ }^{9}$

The clerks themselves were not easy recipients of the new discourse. Long-time derogation and social abuse by an agrarian and buildingoriented society brought many of them to doubt the potential of ideological conviction and political correctness in overcoming social inferiority. Traditional fears of employers and incipient social despair, stemming from an image of blocked economic mobility, limited the absorption of a new social terminology and assured the persistence of the derogation of clerks and clerical work. Moreover, it made imperative, in the minds of the ideo-

8 D. Weinryb, "Me-Ha-Ba'aiot Ha-Sotsiologiot Ba-Arets [Among the Sociological Problems of the Country]", Mozna' im, 5:29 (Sivan 5679) [May-June 1937], pp. 539-547; J. Metzer, "'Hon Leumi' Ke-Musag Yesod Ba-Tsionut: Hashkafat Ha-Olam Ha-Kalkalit BaMachshava Ha-Tsionit, 1918-1921 ['National Capital' as a Basic Concept in Zionism: The Economic World View in Zionist Thought, 1918-1921]", Falk Discussion Papers, 763 (Jerusalem, 1976); M.R. Bessinger, Scientific Management, Socialist Discipline and Soviet Power (Cambridge, MA, 1988). The discrepancy between the clerks' improving economic status and low social and cultural prestige is elaborated in my "National Construction of Occupational Identity: Jewish Clerks in British-Ruled Palestine", Comparative Studies in Society and History, 39, 2.

9 Yoman Mazkir Histadrut Ha-Pekidim [The Diary of the Secretary of the Clerks' Union (Akiva Globman)] (February-July 1931), LA/236-2-229; Y. Shohami, "Ba'aiat Ha-Pakid Ha-Ivri Ba'aretz [The Problem of the Jewish Clerk in Palestine]", Ha-Poel Ha-Tsair, 27 March 1946, pp. 10-11: Z. Carmi, "Neged Rigshei Kipu'ach Ve-Haflaya [Against Feelings of Deprivation and Discrimination]", Shurot, 208 (April-May 1959), p. 4. 
logues of the Clerks' Union, the efforts to construct a cuitural argumentation of productive clerking. No wonder therefore that one of the principal roles undertaken by the Clerks' Union was the acculturation of the clerks to their own social usefulness, to the national and social worth of their productivity. As we shall see in a moment this was meant to be achieved by reinterpreting dominant notions of productivity. However, it was initially based on borrowing these notions which were well embedded in Zionist imagery. ${ }^{10}$

In the first place it was crucial for the clerks to present their work as essential for the construction of Zionist society. By manning, administering and operating services the clerks could pride themselves on producing an infrastructure for the Jewish national home. Emphasis was laid on the clerks' role in the creation of the preconditions for the operation of other economic forces. The "circulatory role" of the commercial clerk was to ensure the unhampered movement (or "metabolism") of economic materials and goods between sectors, and between producers and consumers. Office clerks, particularly those working in Zionist institutions, were depicted as instrumental in establishing the future state-machinery, and as wholeheartedly identifying with the national project. "In fact", defined a contemporary Jewish sociologist, "the fate of each country is to be found in its great part in the hands of the administrative-technical machinery", especially in Palestine where bureaucracy had to be built from scratch." The fact that clerks "produced for others" did not mean that they were unproductive, as the scornful pioneering and agrarianoriented discourse would have it; for, as one writer already claimed in 1919, "Productive work is any work needed for the existence of society" and, in the spirit of many collectivist and nationalist Zionist sources, the clerks were "[.. .] A part of the working machine of the people"."

Likened to Zionist pioneers the clerks became pivotal in animating the economy, the clerk being, as one wrote in 1921, "The living spirit and

10 Y. Zandbank, "Pe'ulateinu Ha-Tarbutit, Tafkide-ha U-Keshaye-ha [Our Cultural Action, Its Roles and Difficulties]", Pinkas (April 1935), pp. 4-10; G.A. Zavol, "She'elot Ha-Peula Ha-Tarbutit Bein Pekidei Ha-Mischar [The Questions of Cultural Action Among Commercial Clerks]", in Ha-Kinus Ha-Artsi Ha-Rishon Shel Pekidei Ha-Mischar [The First National Convention of Commercial Clerks] (Tel Aviv, May 1938), pp. 18-21. For background see M. Levin, Erchei Cheura Ve-Kalkala Ba-Ide'ologia Shel Tekufat Ha-Haskala [Social and Economic Values in the Ideology of the Enlightenment] (Jerusalem, 1975), chs 4-5.

" D.B. Weinryb, "Me-Ba'aiot Ha-Pekidut Ha-Yehudit [Among the Problems of Jewish Clerks]", Shurot, 4 (December 1938), p. 540. See also R., "Matsav Ha-Pekidim Be-Eretz Israel [The Condition of the Clerks in Palestine]", Michtav Chozer, Agudat Ha-Pekidim, Yafo (1922), 3-6, LA/IV-143-25; N. Meltser, "Ha-Matsav Ha-Kalkali Shel Pekidei HaMischar [The Economic Condition of the Commercial Clerks]", in Ha-Kinus Ha-Artsi Ha-Rishon, pp. 5-9.

${ }_{12}$ Ger, "Ha-Pekidut Ha-Tsiburit [Public Clerking]", Ha-Poel Ha-Tsair, 15-16 (15 Nissan 5679) [15 April 1919]. See also N. Ben-Shalom, "Ramat Ha-Chaim Ve-Odef Pekidim [Living Standards and Clerks' Surplus]", Shurot, 11/12 (Febnuary 1940), p. 12. 
main wheel that brings into motion the machine of every institution." ${ }^{13}$ If society, and labor in particular, considered agricultural laborers as its soldiers and heroes, then the clerks were regarded as the home army providing for the needs of those at the front. This was made clear during the 1930s but even more so following the 1948 war. "Public clerking has been enlarged following the set-up of sophisticated governmental machinery", claimed the leader of the Clerks' Union, "[ . . . We must increase the labor capacity, to raise labor productivity so we could run a straightened bureaucracy with enormous labor power." 14

This logic was later linked to the revitalization of capitalist activity:

To the three basic factors [. . . ] land, labor and capital, one must add in our times a fourth factor - administration. The engineer, and with him all the technical machinery, was considered formerly residual, or part of the administration which aided capital to exploit the worker [...] His contribution to existing values was considered [only] an addition to work. Today [...] the intellect is included in the four basic factors of the economy, on which not only the technical advance but the general progress of society depends. There is no way to regulate social life without appreciating the role of the administrative and mental machinery as a thing of itself and with a value of its own. ${ }^{15}$

Administrative productivity was often linked with social utility and national worth. ${ }^{16}$ The "huge administrative machine" was needed to absorb the immigrants and provide, by "treatment clean of bureaucracy" for their needs, particularly in cataclysmic periods such as the Holocaust. Like Zionist pioneers the clerks "produced" the future builders of the Jewish entity in Palestine, a role that distinguished them from Jewish clerks in the Diaspora. ${ }^{17}$

This source of productivity was economically valuable, so it was argued, because it enlarged the wealth of the Jewish economy, particularly in urban areas where most of Yishuv society lived. However, as a town-

13 A.Y. S.H., "Ha-Pakid Ve-Ha-Yeshuv [The Clerk and the Jewish Settlement]", in Michtav Chozer, pp. 2-3.

14 A. Globman, "Shalosh Ha-Mesimot [The Three Assignments]", Shuror, 98 (January 1950), p. 4. See also M. Krupnik, "Histadrut Ha-Pekidim [The Union of Clerks]", Kuntres, 258 (2 Iyar 5686) [16 April 1926]: D. Smilanski, "Min Ha-Yamin Ha-Rishonim [From the First Days]", Pinkas, 1 (March 1930), pp. 21-24.

" M. Benenson, "Chelko Shel Ha-Pakid Ba-Mivneh Ha-Chadash [The Role of the Clerk in the New Structure]", Shurot, 31 (July 1943), pp. 5-6.

${ }^{16} \mathrm{Z}$. Ben-Ya'akov, "Yeilut Be-Avoda Misradit [Efficiency in Office Work]", Shurot, 140141 (August-September 1953), p. 16.

17 "Me-Hirhurei Pakid [Some Clerk's Thoughts]", Shurot, $37 / 38$ (March-April 1944), p. 13. See also M. Nemirovski, "Ha-Pekidim Ha-Ivrim Be-Eretz-Israel [Jewish Clerks in Palestine]", Mischar Ve-Ta'asia, 14 (1929), p. 236; Y. Levi, "Ha-Pakid Ha-Meurgan BeMedinat Israel [The Organized Clerk in the State of Israel]", Shurot, 96/97 (December 1949), pp. 4-5; E. Bonneh, "Be-Sha'ar Niveinu [At the First Page of the Bulletin of the Workers of Haifa's Municipality]", Niveinu, 13 (January 1951), pp. 3-6; D. Ben-Gurion, "Be-Yom Pekuda [At the Day of Reckoning]", Shurot, 41 (August 1944), p. 3. 
dweller the clerk was also an essential consumer of Jewish produce (from vegetables to cupboards, pencils and Jewish insurance), thus occupying a strategic urban stronghold in supporting the newly built economy. In the commercial establishment the clerk recommended Jewish retailers to prefer Jewish over Arab (or any other "foreign") produce. In the offices clerks were in an influential position to persuade their superiors to buy Hebrew materials and equipment, thus producing a nationally-oriented consumption culture. Production of things Hebrew and consuming Jewish produce were thought of as core actions in the construction of a nationallysegregated Jewish entity. ${ }^{18}$ Moreover, during the 1940 s it became conventional to depict administrative produce as supporting national industrial production, and the emergence of industrial clerks was perceived as assuring the economic advancement of the Jewish settlement as a whole. The role of the clerk in the industrial boom during the Second World War was a mere validation of the fact that clerical occupations were essential production factors, like agriculture and building, on which economy and society depended. ${ }^{19}$

The clerks' role in constructing the Jewish national home and the state was a natural corollary of these borrowed arguments and images. Services and administrative productivity were considered as necessary means in the actualization of the state. The Labor-Zionist clerk identified with administrative production just as the agriculturalist identified with the produce of the nationally-owned land, the industrial worker with preparing an industrial infrastructure, and the builder with changing the landscape of Palestine in favor of the Jews. In this way the office was a land to be tilled, bookkeeping was likened to paving a road, brain-work became hand-work, and administration imagined as an industrial good to be produced. ${ }^{20}$

"A. Globman, "Amida Meusheshet [Firm Standing]", Pinkas, 19 (October 1936), pp. 3 4; Meltser, "Ha-Matsav Ha-Kalkali", pp. 5-9; L. Klein, "Hilchot Mechira Be-Veit HaMischar [Selling Practices in a Commercial Establishment]". Shurot, 4 (December 1938), pp. 10-11; D. Misradai, "Ovdei Ha-Misradim: Eich Itmechu Ba-Ta'asia [Office Workers How Would They Suppont Industry]". Shurot. 3 (October 1938), pp. 11-12; H. Dagesh " 'Hasneh' U-Bitucho Shel Ha-Pakid [The Hasneh Insurance Company and Clerks' Insurancel", Shurot, 11/12 (February 1940), pp. 18-19; Y. Dotan, "Pirion Avoda Be-Miktsoa Ha-Pekidut [Labor Productivity in the Clerical Profession]", Shurot, 105 (September 1950), pp. 20-21.

19 Ha-Palid Ba-Ta'asia [The Clerk in Industry] (Tel Aviv, 1943), pp. 3-4; A. Glazer, "Ha-Ta'asia U-Pekide-ha [Industry and its Clerks]", Shurot, $37 / 38$ (March-April 1944), p. 2; Benenson, "Chelko Shel Ha-Pakid", pp. 5-6; Ha-Kinus Ha-Artsi Ha-Rishon, p. 6; T. Greenberg, "Na'amod Ba-Mivchan [We Shall Stand the Test]", Shurot, 11/12 (Februrary 1940), p. 8.

20 Y.L. Ben-Tovim, "Pekidim [Clerks]", Pinkas, I (March 1930), p. 28; C. Gavrielli, "Hagana Beinle'umit [International Prolection]". Pinkas, 1 (March 1930) p. 17-20; T. Greenberg, "Tafkid Histadrut Ha-Pekidim Be-Medinat Israel [The Role of the Clerks' Union in the State of Israel]". Shurot, 90 (June 1949), pp. 2-3; S. Keren-Tsvi, "Charashnu, Zara'anu Ve-Gam Katsamu: La-Kenes Ha-Artsi Ha-Shlishi Shel Ha-Ovdim Ha- 
State-making turned clerical work ever more significant. "As loyal citizens in the state of Israel we are interested in increasing labor productivity, in raising production and in enhancing the export", wrote one clerical activist in May 1950. "The question of labor productivity is now at the head of our concerns", argued another writer in the same year:

But when discussing it somehow nobody mentions one of the more important branches of ours, on which to a large extent depends the future of our production the clerk. [...] Any physical action and physiological process are closely linked with psychic activity, with the action of the brain; and underproduction or inability in the mental field will necessarily cause inefficiency also in physical work. The engineer's lay-out, the ordering of crude material, the clerk's response to letters, a correct ordering of the warehouse, the matching of the cashier and book-keeping [...] all these contribute to the general raising of (the industrial and administrative) productivity or to its weakening. ${ }^{21}$

Thus essential ingredients of the dominant physiocratic, constructivist and industrial Zionist repertoire of productivity were reproduced. The clerks' produce became material as any other, and its clerical producers were included among the pioneers on whom the new constructed society could depend. As a source of ordered, well-administered economy and valuable urban consumption, collective administrative production made the Jewish economy viable and autonomous. The clerks' dedication to work reflected the classical Labor-Zionist linkage between the collective of producers, the labor process and the national significance of their product. The designation of clerking as unproductive, and the popular contrast between productive and unproductive labor, could be thus done away with; and the cultivation of a positive, legitimized and socially-significant bureaucratic ethos was made possible. The reproduction, by vital segments of town society, of Zionist conceptions of worth and social utility was thus assured.

The effect of this terminology was meant to be wide as the images and verbal manipulations were forwarded to the clerks, to the Histadrut and to Yishuv society. Moreover they were perceived, at one and the same time, as advancing the clerks" prestige, reducing their "panic-status", and enhancing collective national socialization. It served the clerks in the formation of their singular occupational identity, and in promoting their claim to be accepted as valuable servants of the Zionist cause. As long as work remained an influential parameter of social significance, and the mythologization of productivity persisted, no better strategy in the Yishuv's urban politics of status was available. Neither was there a more

Munitsipali'im [We Ploughed, Sowed and Reaped: On the Third National Convention of Municipal Workers]", Shurot, 172 (April 1956), p. 5.

"For the first quotation see Karni, "Talkid Dachuf", p. 5. For the second see Y. Dotan, "Pirion Avoda Be-Avodat Ha-Pakid [Labor Productivity in the Clerk's Work]", Shurot, 104 (August 1950), p. 14. See also A. Govrin (Globman), "Bedek Ha-Manganon [Bureaucracy Repair]", Davar (5 December 1948). 
influential factor in the Zionist mobilization of town society. However, for a wider reception of these discursive practices a further and more effective step had to be taken, namely the imbuing of productivity with new contents. $^{22}$

\section{PRODUCTIVITY TRANSFORMED}

While the reproduction of the Zionist productivist conceptions and its dissemination in town society was based on pioneering and traditional constructivist and agrarian-oriented notions, its transformation, in which clerks played a major role, was modernist and even utopian. Based as they were on an explicit argument regarding the inseparability of technological modernism and nationalism, the alterations inserted stressed the subjective and relational character of productivity. Four elements of this transformed meaning of productivity stand out: production of modem style of service, productive knowledge, manufacturing of control, and rationalization. In this reformulation of the current Zionist understanding of productivity the clerks sought to transfer the struggle for legitimation to their own grounds, where they could best satisfy the Zionist quest to appear modem. ${ }^{23}$

The creation of a modern style of public service in Palestine was claimed by many writers in clerical newspapers and bulletins as a significant innovative and productive output. The clerk "invented" a culture of public politeness and propriety, expressed both by the treatment of clients at the office, and by serving as a model of public behaviour for the rest of society. By creating order, precision and tidiness the clerks "produced" exemplary workers and model workplaces, thus offering themselves as a source of novel and much-needed values for a new modern society. "We have to recognize the most important principle of the work of the officeworker", claimed one writer in 1926. "Not the public serves the office but the other way around; the absolute raison d'etre of the office (and its employees) is to provide for the needs of, and be of service to the public."

By serving the client gently, dextrously and patiently the commercial clerk did not only serve the Zionist capitalist but also produced new values

\footnotetext{
${ }^{22}$ Ha-Mo'atsa Ha-Tesha-Esreli Shel Histadrut Ha-Pelidim [The 19th Council of the Clerks' Union], October 1950 (Tel Aviv, 1951); see also H. Braverman, Labor and Monopoly Capital: The Degradation of Work in the Twentieth Century (London, 1974), pp. 410423; R. Sobel, The White Collar Working Class: From Structure to Politics (New York, 1989), pp. 29-30. For "panic-status" see C.W. Mills, White Collar: The American Middle Classes (London, 1956), pp. 239-249.

${ }^{23}$ B. Katsenelson, "Ovdei Ha-Mada Le-Sherut Ha'am [Scientific Workers in the Service of the People]", Shurot, 42 (September 1942), pp. 1-8; See also J. Herf, Reactionary Modernism: Technology, Culture and Politics in Weimar and the Third Reich (Cambridge, 1984), pp. 1-16, 183.

${ }^{24}$ Krupnik, "Histadrut Ha-Pekidim".
} 
and educated society respectively. ${ }^{25}$ Inculcation of modern style of public behaviour was a matter of value production, as were precise organization, order and cleanliness. Implicit here was a contrast with Jewish miserable (and thus non-productive) conditions in the Diaspora, and with images of Palestine's Arabs. One can imagine how this logic could easily turn productiveness into legitimating a selection of Jewish immigrants on the one hand, and segregation from Palestinian Arabs on the other. In the same vein the responsibility to educate the public to modernity was closely connected with educating town society to consume Hebrew products, as both were oriented to strengthen the Jewish economy and bring about national autonomy. ${ }^{26}$ The establishment of the state tumed these images into a conventional imagery; as one writer bluntly argued in 1950:

The clerk [... .] mediates not only between man and society. The clerk is a public educator [... J Jewish clerical work creates in the country cultural and mental climates. In this it proves to be a constructive force [...] The clerks are the civilian standing-army of the state. The citizens of this young state are still of need of civilian education. ${ }^{27}$

This cultural production resembled the public-educational role of the pioneer and agricultural worker, but it went a step further as bureaucracy became a positive and a crucial factor in the new Jewish society. The notion of service to the nation and to state-building was thus transformed into a product, the measurment of which was social and collective.

The production of professional knowledge was no less important. The emphasis on the effectiveness of knowledge was not entirely novel to the Zionist notion of the "technical expert" and the intellectual worker (Ha-Poel Ha-Intelligenti). However, the clerks' self-acclaim for producing knowledge introduced a new element. Clerks produced quantitative knowledge in accounting, administration and the ordering of production, all these being essential values in the economic making of the Yishuv. The clerk needed to use professional quantitative methods in order to produce greater amounts more efficiently. The accumulation of statistics and the production of quantitative analysis were instrumental in evaluating the economic capacity of the Yishuv to absorb Jewish immigration, in easing

29 A.M., "Tafkid Ha-Oved Be-Mosad Tsiburi Ve-Histadruti [The Role of the Worker in Public and Histadrut Institution]", in Histadrut Ha-Pekidim, Senif Cheifa [Haifa Branch of the Clerks' Union], Bulletin, 2 (January 1931), pp. 2-3.

${ }_{26}$ D. Flanberg, "Mitsvot Asseh Le-Pekidei Ha-Mischar [Practical Commandments for Commencial Clerks]", Pinkas, 25 (December 1935), pp. 22-23; H. Ben-Abba, "Ha-Pakid Ha-Memshalti Ve-Ha-Tsibur [The Government Clerk and the Public]", Shurot, 104 (August 1950), pp. 16-17. For theoretical inspiration see M. Douglas, Purity and Danger: An Analysis of the Concepts of Pollution and Taboo (New York, 1966).

27 T. Greenberg, "Tarbut Ivrit Ve-Hinuch Ha-Pekidim [Hebrew Culture and Clerks' Educa. tion]", Shurot, 108 (December 1950), pp. 6-7. 
unemployment and in counting voters in the intensive electoral events of the Histadrut and the Yishuv. ${ }^{28}$

Qualitative knowledge was equally significant, for it turned the natural material character of quantitative knowledge into what was considered as an abstract product. Policy papers produced by clerks were advanced as indispensable tools in the daily workings of the Zionist organization, and in improving their effectiveness. Periodic reports, summed up and edited by clerks in the Histadrut economic institutions, labor councils and trade unions reflected clerical efficiency and productivity. The clerks in industry, banking and insurance companies were depicted as the precursors of the know-how of management in Palestine's modern economy. The origin of the notion that management was nationally important, and should be nationally-oriented, could be found here, in the image of the high-ranking productive and trustworthy clerk. ${ }^{29}$

Stenography and accountancy, considered at the time as semiprofessional occupations, were thought to endow clerking with a higher status because of the knowledge involved. .The office of tax collecting, filing and auditing in the Zionist Agency was metaphorized as a scientific laboratory producing vital information for the mobilization of society and its formal control. Producing knowledge, quantitative and qualitative, material and abstract, was promoted by the clerks' ideologues as a precondition for modem organization, and for the modem make-up of society as a whole. The work environment of the clerk was thus portrayed as a point of technical advancement and knowledge production, the locus of service and construction of knowledge, the actualization of the ouvrierist notion of the Zionist project as an enterprise (Ha-Mif'al Ha-Tsioni)..$^{30}$

${ }^{28}$ Y. Dotan, "Torat Ha-Statistika Ve-Ha-Diagrama [Statistical and Diagramatic Theory]", Shurot, 101 (May 1950), pp. 11-14.

${ }^{29}$ Hachlatot Mo'etset Histadrut Ha-Pekidim [Resolutions of the Council of the Clerks' Union] (17-19 December 1931), in Din Ve-Cheshbon Shel Histadrut Ha-Pekidim LaVe' ida Ha-Revi' it Shel Ha-Histadrut Ha-Klalit [Union of Clerks' Report to the Histadrut Fourth General Convention] (1933), pp. 26-29; A. Bonneh, "Al Hachsharat Pekidim LeMeshek U-le-Hanhala [On Training Clerks for Economic Administration and Managementl", Shurot, 33 (October 1943), p. 11; S. Achituv, "Pekidei Ha-Ta'asia Ve-Ha-Medina Ha-Yehudit [Industrial Clerks and the Jewish State]", Shurot, 76 (January 1948), pp. 3-5. See also J.R. Dale, The Clerk in Industry (Liverpool, 1962), ch. 3; Y. Reuveni, Ha-Minhal Ha-Tsiburi Be-Israel: Hamanganon Ha-Memshalti Be-Israel Ve-Hitpatchuto Ba-Shanim 1948-1973 (Public Administration in Israel: The Government Bureaucracy and its Evolution in the Years 1948-1973] (Ramat-Gan, 1974); I. Troen, "Yetsirat Madaei Chevra Tsioni' 'im: Chishuv 'Kosher Ha-Klita Ha-Kalkali' Shel Eretz-Israel [The Creation of Zionist Social Science: The Calculation of Palestine's 'Economic Absorptive Capacity']", Iunim Be-Tekumat Israel, 1 (1991), pp. 481-495.

${ }^{30}$ B. Repetor, "Ha-Pakid Be-Tenuat Ha-Avoda [The Clerk in the Labor Movement]", Pinkas, 11-12 (February 1937), pp. 8-10; Y. Mimon, "Ha-Stenograph Ve-Darchei Umanuto [The Stenographer and the Practices of His Art]", Shurot, $11 / 12$ (February 1940), pp. 14-15; Y.A., "Roe'eh Ha-Chesbon Ha-Musmach [The Authorized Accountant]", 
The production of means of inspection and control was naturally the next stage. The centralized manner of the clerks' work, purported to control inferior assistants, was thought of as a model for administrative efficiency and for the control of human resources in the economy in general. ${ }^{31}$ Through the cultivation and dissemination of the norms of orderliness and precision the clerks made inspection possible, and produced modem means of managing the Zionist project. They presented themselves not only as providing mere services, administrative knowledge and bureaucratic structures, but as creators of stately instruments of operative and sanctioning character. The ordering of knowledge allowed the administration of local labor communities, urban neighborhoods and countrywide organizations; and at the same time their integration into a whole, their centralization under a commanding center. The clerks thus enabled the control of the environment, its order and stability: "The worker creates something from nothing, turns wilderness into blossom, constructs roads, turns crude matter into a working instrument. The clerk orients and regulates what exists. Without him all would end in chaos."32

Just as administrative control was so crucial in conditions of presovereignty, so was the production of social control and means of effective inspection. The rules laid down by industrial clerks in their respective workplaces, the detailed collective contracts the clerks signed in large public institutions, and the persistent concern with ordered and controlled behaviour during work-time, all were advanced as testifying the clerks' merit as producers of a disciplinary space and restrained society; in themselves crucial means of social integration. In this sense productivity was transferred from the economic plain to politics. Without clerks and clerical work, so claimed the clerks' ideologues, it would have been impossible for the politicians to run society; for on the clerks centered all the planning, the researching, the collection of material and its analysis. This was the very true sense of building the state. ${ }^{33}$

Shurot, 11/12 (February 1940), p. 16; "Petach Davar [Preface]", in Histadrut Ha-Pekidim, Din Ve-Cheshbon Le-Mo' etset Ha-Sochnut Ha-Yehudit [Report of the Clerks' Union to the Council of the Jewish Agency] (1943-1944), p. 3; T. Greenberg, Tarbut lvrit Ve-Hinuch Pekidim [Hebrew Culture and Clerks' Education] (Tel Aviv, 1951); Shifra, "Ba-Ma'abada Shel Lishkat Hamas [In the Laboratory of the Tax-Collecting Office]", Shurot, 87-88 (February-March 1959), p. 5.

${ }^{31}$ Weinryb, "Me-Ha-Ba'aiot Ha-Sotsiologiot Ba-Arets", p. 542.

${ }_{32}$ Pakid Vatik [A Veteran Clerk], "Bein Ha-Pekidim Le-Vein Atsmam [Among the Clerks and Themselves]", Shurot, 36 (Febsuary 1944), p. 8.

${ }_{33}$ D. Remez, "Oved Ha-Histadrut [The Histadrut Worker]", Alon Le-Personel Kupat Cholim [Bulletin of the Staff of the Histadrut Sick-Fund] (February 1936), pp. 6-8; "HaPeula Ha-Miktsoi' it Ve-Kivuna [Union Action and its Orientation]", Histadrut HaPekidim, Doch La-Vei'ida Ha-Chamishit [Report to the 5th Convention of the Clerks' Union] (1933-1941), p. 19. For disciplinary space see M. Foucault, Discipline and Punish (Harmondsworth, 1979); and A. Giddens, The Constitution of Sociery: Outline of the Theory of Structuration (Berkeley, 1984), pp. 145-158. Compare also with the notion of 
Economizing became a value to be produced, and thus the epitome of the clerks' transformation of the traditional notion of productivity. Saving was the real sign of modernity as it eased the development of modern municipal and state bureaucracies, and reallocated economic functions in a rationalized and efficient manner. It caught central place in the clerks' discourse, particularly after the great economic crisis of the mid-1920s and the economic downtum of the mid-1930s. Later it played a major role in the rationalization of governmental administration. ${ }^{34}$

The clerks appeared as chief importers and promoters of rationalization and efficiency. Among the foundations of modernity the latter stood out both as values to be cherished and as a philosophy of practice. The clerks embodied efficient methods of organization and operation, which resulted in saving time and space and keeping costs down. Taylorite notions were revered by the ideologues of the clerks, though they protested against its human cost. The application at the office of scientific management and rationalization also meant offering the well-managed office as a model for other sectors. The inculcation of efficient modes of administration, the actual importation of Taylorism to Palestine, and the unambiguous support of office mechanization and automation, were supposed to bring collective status and prestige. Stenographers produced speed and efficiency, they were "midwives" of technology, and taught other service and bureaucratic sectors how to save energy. ${ }^{35}$

The changing nature of clerical output during the 1940s confirmed the logic of using productivity for acquiring social prestige. Industrial clerks, becoming a large force during the war, perceived themselves as responsible for introducing economic rationalization and efficient methods of production, providing for both capitalist development and national construction. Efficient clerks, so it was argued, assumed national roles; and as they introduced Hebrew terms into office work they allowed the adaptation of the nascent national language to the new conditions of state-building. ${ }^{36} \mathrm{In}$

the political transformation of rationalization in G. Kolko, The Triumph of Conservatism (New York, 1977).

${ }^{*}$ C. Gavrielli, "Ha-Politika Ha-Ta'arifit Shel Histadrut Ha-Pekidim [The Tariff Politics of the Clerks' Union]", Chovert Le-Inianei Ha-Pekidim (1929), pp. 14-22; Histadrut HaPekidim, Alon Ha-Va' ad Ha-Merkazi [The Bulletin of the Central Committee of the Clerks' Unionl, 7 (June 1934), p. 3.

${ }^{35}$ Y. Mimon, "Al Ha-Stenographia Ve-Atidote-ha [On Stenography and its Future]", Chovert Le-Inianci Ha-Pekidim (1929), p. 30. See also Editorial, "Min Ha-Tsad [On the Side]", Shurot, 82 (August 1948), p. 7. For various cases of Taylorite practices see J.A. Merkle, Management and Ideology: The Legacy of the International Scientific Management Movement (Berkeley, 1969). Compare with an earlier American example in I.A. De Vault, Sons and Daughters of Labor: Class and Clerical Work in Turn-of-the-Century Pittsburgh (Ithaca, 1990).

${ }^{36}$ Y. Berman, "Havu Lanu Sefarim Miktsoi' im [Give us Professional Books]", Pinkas, 3 (October 1935), p. 20; D. Remez, "Efod Bad [Cloth Efod]", Pinkas, 6-8 (April 1936), pp. 3-5; D. Horwitz, "Ha-Sikui'im Ha-Kalkali' im [The Economic Prospects]", Shurot, 56 (December 1945), p. 3; F. Naphtali, "Yesodot Ha-Seder Ha-Kapitalisti [Foundations of the 
the early $1950 \mathrm{~s}$, when state-building materialized, economic output was depicted as dependent on clerking, on design and planning, on saving time and energy, and on scientific order; proving that "a public of professional clerks is a blessing to the state and to itself ". ${ }^{37}$ Rationalization became an issue of national survival, as one writer explained: "For waste of human labor and time is a crime against the national economy of our state." Through the "modernization" of productivity the clerks turned and, as is shown in the next section, were idealized as turning, from educating society to modem life, into moral guardians of the new state. ${ }^{38}$

\section{PRODUCTIVITY PRESCRIBED}

Part and parcel of the "modemization" of Zionist conceptions of productivity, and their dissemination in town society, was the prescription of the necessary and conducive conditions for the realization of the clerks' productive qualities. This prescriptive aspect touched upon the issues of self-improvement and upward mobility, in themselves a reflection of group interests. Despite its self-interested orientation, and perhaps because it was based on more sophisticated notions of improvement struggles that could apply to many other occupational groups, this aspect of the social construction of productivity had an enormous influence beyond the clerks' circles.

First the clerk and clerical work had to be singled out. To be productive and useful, in the social and national senses, the clerk had to be professional and relate to his or her occupation as a profession. "In clerking what generally counts is quality," wrote an early management expert in 1952:

For here there is not an issue of output and production units, but the work of the mind, and there is a way to determine a norm of standardization of thoughts and ideas. The latter are subjective elements, the productivity of which is not only the fruit of effort, but the end-result of the personal qualifications of the clerk, such as his general level, his professional knowledge, the extent of his intelligence.

Capitalist Order]", Shurot, 68 (April 1947), p. 2. Y. Dochan, "Va'adot Ha-Yitsur U-Pirion Ha-Avoda [Production Committees and Labor Productivity]", Shurot, 94/95 (October-November 1949), pp. 12-14; Ben-Ya'akov, "Ye'ilut Be-Avodat Ha-Misrad", p. 16; T. Ben-Ya'akov, “Irgun Ya'il Shel Avodat Ha-Misrad [Efficient Organization of Office Work]", Shurot, 146 (February 1954), p. 10. See also M. Frenkel, "Idiolog'iot Te'us BeFalestina-Ai: Bein Te'us Le-Le'umiut, Ha-Mikreh Shel Chevrat Ha-Ashlag [Industrialization Ideologies in Palestine, Between Industrialization and Nationalism, The Case of Palestine Potash Limited]" (M.A. dissertation, Tel Aviv University, 1992), pp. 100-101.

${ }^{37}$ Dotan, "Pirion Avoda Be-Miktsoa Ha-Pekidut", p. 21. See also Dotan, "Pirion Avoda Be-Avodat Ha-Pakid", pp. 14-16; M.G., "Lama Ne'edar Mekomo Shel Ha-Pakid? [Why was the Clerk Made Absent?]", Shurot, 104 (August 1950) p. 17.

${ }^{38}$ Devoskin, "Rationalizatsia Be-Avodat Ha-Misrad", p. 7. See also Z. Carmi, "LeBa'ayat Ha-Tefuka Ba-Sherut Ha-Tsiburi (On the Problem of Output in the Public Service]", Shurot. 178 (October 1956), p. 5. 
And as to the professional aspect the author went on to argue that:

There is no other way to improve the technical equipment of the clerk in order to raise his productivity, for his utensils are his experience and his know-how. To measure this kind of productivity, reflected as it is in efficient organization and planning, is possible only by assessing the general progress of the enterprise or the institution. In this case the basis for raising the work productivity of the clerk is his professional profficiency. ${ }^{39}$

Thus, in the clerical rhetoric collective, material and objective measurement of productivity was transformed into individual, abstract and subjective conceptions. Clerical productivity demonstrated not only the flexibility of the definition of productivity but also the variety and non-definitive means of its measurement. This was the implication of redefining productivity, for the latter entailed both the redefinition of its evaluation and its advancement as a social creed.

Since the early 1920 s the clerical discourse determined the startingpoint of professionalization by appealing to all clerks to become knowledgeable in accountancy, to acquire many languages and specialize in stenography and typewriting. Professionalism meant to set the clerks apart from the rest of labor, but at the same time to serve as its model. Zionist institutions were asked to consider professionalization as the realization of the national interest, and were called to finance it. ${ }^{40}$ The images of scientificity and professionalism further emphasized the close links between training, productivity and utility. This was made clear as early as 1925 by the activists of the Haifa branch of the Clerks' Union:

The main precondition determing the clerk's working life is: the improvement of his knowledge and professional training. One can surely say that the employer's attitude towards us is related to the extent of utility accrued from our work. It is thus a duty of each one of us to improve knowledge in all aspects of office work, for by that he acquires his employers' trust and sympathy. ${ }^{41}$

${ }^{39}$ A. Globerson, "Le-Ba'aiat Pirion Avoda Be-Pekidut [On The Problem of Labor Productivity in Clerical Work]", Shurot, 124 (April 1952), p. 7. See also A. Almagor, "Ha-Arachat Pirion Ha-Avoda Shel Ha-Pakid - Keitsad? [The Evaluation of Labor Productivity of the Clerk - How?]", Shurot, 122 (February 1952), p. 4.

40 "Khronika [Chronicle]", Ha-Achdut, 34 (25 sivan 5674) [19 June 1914]; Echad HaPekidim, "Hishtatfut Ha-Pekidim Ba-Asefa Ha-Meyasedet [The Participation of the Clerks" in the Founding Assembly]", Ha-Poel Ha-Tsair, 20 June 1919; R.D. Sola Paul (of the Jewish Delegates' Committee 10 Palestine) to M. Lederer (of the Clerks' Union), 12 January 1920, LA/143-9.

${ }^{11}$ Karoz Le-She' elon Le.Pekidim. Shel Va'ad Agudat Ha-Ovdim Be-Misradim U-Be-Vatei Mischar Be-Cheifa [A Questionnaire for Clerks, Announced by the Committee of the Haifa Union of Clerical and Commercial Workers, 16 January 1925], LA/236-1-82. See also Zavol, "She'elot Ha-Peula Ha-Tarbutit Bein Pekidei Ha-Mischar", pp. 18-21; Katzenelson, "Ovdei Ha-Mada Le-Sheurt Ha-Am", p. 108; Y. Dotan, "Ha-Katvanit U-Mechonat HaKetiva [The Woman-Typist and the Typewriter]", Shurot, 98 (January 1950), pp. 14-16; Y. Dotan, "Re'iat Cheshbon Be-Yameinu [Accounting Nowadays]", Shurot, 99 (February 1950), pp. 10-11. 
Accounting was no longer considered as an occupation that could be acquired autodidactically; and it turned into a formalized profession that had to be taught and learned in a formal institution. Typewriting, a muchneeded function in bureaucratized societies, was portrayed as a profession in need of specialized training by authorized instructors. To determine who was able the clerical discourse contained a "scientific" list of necessary qualities, thereby creating a grading of social prestige: orientation, quick perception of important issues, good memory, phrasing ability, concentration capacity, memory for written signs, finger dexterity and quick adaptability to various typewriting machines. These qualities were the clerks" "weapons" in improvement struggles, as wrote a union activist in 1950:

The work confidence of the clerk, equipped with sufficient professional information, is much greater than the one who does not have this information; lack of sufficient knowledge is a fertile ground for a sense of inferiority and submission to the pressure of the employer. Professional learning and deep professional knowledge bring pride, solid and independent status, and does not compromise the demands of the clerk. As all that springs from the clerk's feeling and sensible recognition that he fulfills a useful role to society, the people and the state. ${ }^{42}$

Through professional clerking, so it was argued, labor at large could be presented as executing a scientific work. The harnessing of professional work to the national cause, and the regimentation of obedient bureaucrats and technical experts to the authority of the politicians, were integrated, and made to appear as carrying political significance. Moreover, the language of professionalism set boundaries. In the conditions of pre-state Palestine specialization meant closing the ranks of the clerical profession to immigrants, the unemployed and other workers. Added to the traditional Zionist imagery of productivity the new exclusionary notions of professionalism proved very effective, as they served the singularization of the practisers of the occupation, without socially setting them apart. ${ }^{43}$

The creation of the productive clerk made imperative the "cultivation of the body", and the "physical devotion" of the clerk to administrative work and to the office. As the clerk was a vital part in the "national machine" his productive energy, as one writer claimed in 1919, had to be preserved and the body had to be guarded, "so he could work and gatner

42 Kami, "Tafkid Dachuf", p. 5.

43 "Mitsvot Asseh Shel Pekidei Ha-Bankim [Practical Commandments for Bank Clerks]", Histadrut Ha-Pekidim, Alon Ha-Va'ad Ha-Merkazi, 7 (June 1934), pp. 18-19; Y. Dotan, "Torat Ha-Statistika Ve-Ha-Diagrama [Statistical and Diagramatic Theory]", Shurof, 102 (June 1950), pp. 14-17; Y. Levi, "Hachshara Miktsoit Le-Pekidim - Keitsad? [Professional Training for Clerks - How?]", Shurot, 114 (June 1951), p. 6; Shapiro, Ha-Demokratia Be-Israel, pp. 134-144; ; D.J. Penslar, "Mumchim Be-Sherut Ha-Hityashvut Ha-Tsionist [Experts in the Service of Zionist Settlement]", Research Institute for the History of the Keren Kayemeth Le-Israel (Jewish National Fund), Land and Settlement, 14 (September 1994); Penslar, Zionism and Technocracy, ch. 6. 
strength and give birth and grow healthy children". ${ }^{44}$ Moreover, the clerks were presented as particularly in need of rest during work-hours and not exceed a five-day week. Their annual leave was presented as essential to the increase of productivity. These notions exemplified both the appropriation of the health consciousness, characterizing the Zionist discourse of hand-labor, and the role of the clerks' productivity rhetoric in the further inculcation of labor's eugenic way of thinking. ${ }^{45}$

The clerical appropriation of the physical dimensions of the work of the agrarian, construction and industrial pioneers determined the masculine style of the terminology of the clerk's body, despite the invigorating feminization of clerking since the end of the 1930s, and particularly after the establishment of the state of Israel. Furthermore, special reference was made to the importance of space. In order to be productive the woman typist needed a room of her own so as not to be disturbed by the noises around her. "In this room", explained an expert writer

needs be lots of air and light (and when necessary also suitable shadow). In winter the room should be heated and fix temperature needs to be assured (the cold makes it difficult to sit in one place and influences first and foremost the fingers, hands and the legs). It is worthwhile also to see to isolation in order to decrease the noise of the machines [...] It is very important that the room is aesthetically and suitably organized and tidied. It affects the mood and the will to work. ${ }^{46}$

And another writer referring in 1950 to productive abilities added,

Everybody admits that working as a telephonist wrathes the nerves and requires more stamina than any other work. It requires better nutrition and suitable salary. Moreover: working as a telephonist is not so simple that it can be assigned to anyone. It requires intelligence, quick grasping and understanding of the other. ${ }^{47}$

These indirect references to the reality of feminization were significant; for they revealed the sensitivity of the male-dominated Clerks' Union and

4 Ger, "Ha-Pekidut Ha-Tsiburit"; see also B. Chaiut, "Machalot Ha-Atsabim Be-Chayei Ha-Pakid [Nervous Diseases in the Life of the Clerk]", Pinkas, 3 (October 1935), pp. 22 23. For fatigue see Rabinbach, The Human Motor, pp. 136-145, 272.

4s Gavrielli, "Ha-Politika Ha-Ta'arifit Shel Histadrut Ha-Pekidim", pp. 14-22; A.A., "Machalot Miktso'iot Shel Pekidim [Professional Diseases of Clerks]", Shurot, 103 (July 1950), pp. 11-12; Avi-Moshe, "Khok Ha-Chufsha Ha-Shenatit Ve-Ha-Makhsor Be-Vatei Ha-Avra'a [The Law of Annual Leave and the Shortage in Convalescence Homes]", Shurot, 117-118 (September-October 1951), p. 9.

46 Dotan, "Ha-Katvanit U-Mechonat Ha-Ketiva", pp. 14-16.

"Telephonistit, "Ha-Telphonist'iot [The Women-Telephonists]", Shurot, 104 (August 1950), p. 17. Feminization is reflected in the fact that between 1931 and 1961 the share of Jewish women in the Jewish labor force employed in govemmental and public services increased from approximately $\mathbf{1 1 . 7}$ per cent to 20.8 per cent, and their share in the Jewish labor force employed in the private sector of commerce, banking and insurance increased from 10.4 per cent to 27.4 per cent. See E. Mills, The Census of Palestine, 1931 (Alexandria, 1933), vol. II, and Population and Housing Census 1961 (Jerusalem 1961), 21, pp. 18-23. 
its press to the potential decrease of the status of the profession following the increasing share of women therein.

Personal interests were made to appear closely connected with general needs. If the clerks demanded spacious accommodation, new equipment and proper light and air conditioning, it was not only for their good but also for that of their employers, and for the general increase of productivity. "It must be discussed how to build an office", argued a bank clerk:

how to paint it, how to light it, how to air-condition it, how to equip the office with equipment and utensils needed in the right place and proper time: how to organize and regulate work and how to allocate it judiciously so it would be practised rightly and efficiently in the necessary time, and at minimum costs. ${ }^{49}$

Fatigue opposed productivity, and mechanistic adoption of Fordist or American-style of work-tempo was suspected as causing clerical occupational diseases:

The static burden of the body should be decreased. True, sitting itself is easier than standing, but one must inspect the sitting posture, the chairs, the leanings of the body and the foot. According to psychotechnic investigation [...] in most cases sitting is uncomfortable and even tiring. The woman-typist's chair should be so constructed that the back rests in writing and serves for leaning [...] To what extent incorrect posture of the legs hampers work is proven by the fact that the typist occasionally changes the position of the feet. Analysis has shown that the best leaning for the feet that the heel and big toe are leaning. ${ }^{\text {so }}$

Without attention to these conditions rationalization of clerical work was considered impossible.

The ideal clerk was therefore depicted as having not only professional clerical knowledge but a proper character and mental qualities. The enlisting of the clerk's psyche was necessary. He or she was part of a machine, "the parts and joints of which are lively and laboring bodies, feeling and thinking souls". ${ }^{31}$ Their psyche was wholly integrated with their work, for, "organization work is a spiritual work and it should not be practiced routinely"."32

4 Dotan, "Pirion Avoda Be-Miktsoa Ha-Pekidut", p. 20.

49 Devoskin, "Ratsionalizatsia Be-Avodat Ha-Misrad", p. 7. See also Z. Shaket, "Hashpa'at Mekom Ve-Tenaei Ha-Avoda al Pirion Ha-Avoda [The Influence of the Work-Place and Working Conditions on Labor Productivity]", La-Matara: Alon Penimi Shel Pekidei Bank Anglo-Palestinia Be'am Be-Snifiei Cheifa Rabati [On Target: Internal Bulletin of the Clerks of Anglo-Palestine Bank Limited in Branches of Greater Haifa], 3 (November-December 1950), pp. 5-6.

so Dotan, "Ha-Katvanit U-Mechonat Ha-Ketiva", pp. 14-16. See also Chayut, "Machalot Ha-Atsabim Be-Chayei Ha-Pakid", pp. 22-23.

sI Ger, "Ha-Pekidut Ha-Tsiburit".

52 Dotan, "Pirion Avoda Be-Avodat Ha-Pakid", p. 14. See also D. Yohannes, "Paradoxim [Paradoxes]", Shurot, 178 (October 1956), p. 5; M. Idit, "Ta'arucha Le-Ye'ul Misradi Be-Cheifa [An Exhibition in Haifa on Making Office More Efficient]", Shurot, 178 (October 1956), p. 14. 
Mental identification with work was not only individual. As it was closely associated with Zionist nationalism it was considered a prerequisite to achieve better collective performance and increased production by the expanded and cooperating clerical group. ${ }^{53}$ Work loyalty was to be expressed in the diligent clerks, their precision and order in work, the abstention from soldiering, and the utmost dedication during working hours. In 1938 one writer summed up these ideas when he called the clerks to relate to the functional aspects of their administrative work with a religious sense of mental self-sacrifice:

In the long run the intrinsic association between the worker, his work and professional training create work ethic. The intention here is not enclosure, an isolation of a sect, but an attitude to work, to the sense of collective and personal work responsibility, whatever is the worker's position in the enterprise, his salary, his work conditions and the character of the enterprise (public or private). Work itself becomes in a way a mental matter, to which during work-hours the worker devotes all his thoughts. Work is not done mechanically, in order to "do away with it", but in close affinity to it, out of a sense of responsibility to what is being created [...] By itself its productivity also increases. ${ }^{34}$

\section{PRODUCTIVITY EXCHANGED}

As can be gauged from the operation and debating in the various town branches of the Clerks' Union, it was clear to organized clerks from very early on that any change in their social status and prestige depended on material developments and the acquisition of power positions. Without bureaucratization of the Yishuv's statist-like and capitalist structures the clerks' language of productivity would have remained rhetorical. A major part of the discourse related to the fact that the claims for recognition and legitimation could not materialize without some dimensions of the status campaign being translated politically. This dimension, a sort of "productivist politics", should not be thought of separately from the discursive dimension: they were mutually interdependent, and the clerks' ideologues, more than any other unions' leaders in the Histadrut, did not believe advancing in one was possible without the other. ${ }^{5 s}$

At the heart of the clerks' politics of productivity was the notion of exchange. Already in the discursive campaigns described above appeared

${ }^{33}$ R., "Matsav Ha-Pekidim Be-Eretz-Israel", p. 6. See also Devoskin, "Ratsionalizatsia Be-Avodat Ha-Misrad", p. 7; T. Kroy. "Ye'ul Ha-Avoda Ve-Tohar Ha-Midot - Keitsad? [Combining Work Efficiency and Integrity - How?]", Shurot, 159 (March 1955), pp. 8-9. s4 Weinryb, "Me-Ba'aiot Ha-Pekidut Ha-Yehudit", pp. 4-5. See also I. Devoskin, "HaPakid Ve-Ha-Misrad [The Cle1 : and the Office]", Shurot, 122 (February 1952), p. 10; A. Globerson, "Le-Ba'aiat Pirion Ai nda Be-Pekidut [On the Problem of Labor Productivity in the Clerical Profession]", Shurot, 123 (March 1952). pp. 6-7.

ss Maier, In Search of Stability, chs 1 and 3; Nolan, Visions of Modernity. For an earlier discussion see Nadwomy, Scientific Management and the Unions, ch. 9. 
a similar element of social exchange with forces facing the clerks, namely prestige in exchange for service to the Labor and Zionist collectives. However, the clerks did not only ask to prove their utility, but practically bargained productivity and efficiency for improving working conditions. In order to transform what was considered abstract and ambiguous into something practical and viable, the notion of productivity as carrying an exchange value, particularly in labor relations, had to be present. This was demonstrated, for example, during the 1930s in the pressing demand, resisted by employers, for clerks' insurance and its positive potential impact on the increase of productivity. ${ }^{56}$ The use of productivity in the politics of status could thus turn into a relational and political use, a way to increase the clerks' power at work, in the Histadrut's union system and beyond.

Three uses of the exchange value of clerical productivity and utility should be emphasized. The first exhibited the clerks' economic worth as an argument in redundancy struggles. Directing their anger in particular against Zionist national institutions organized clerks demanded to annul the notion that economizing in Zionist expenses could be achieved by making clerks redundant. This struggle, spreading also to municipalities and to the Labor Movement, was one of the fiercest labor disputes of the early 1930s. It reached the debating halls of the Zionist congresses, and threatened to paralyze the workings of the Jewish Agency and its executive departments. It was following this struggle that the clerks could boast of their powerful union position and of the value of their struggles to labor in general, and also in the wider recognition of their major role in the Zionist project. As in other sectors the image of workers' power was closely connected to social standing and national worth. ${ }^{57}$

Secondly, increase of productivity and efficiency were strategically bartered for working conditions. In order to assure an improved clerical work performance the betterment of the clerk's working conditions and the creation of a conducive work environment were necessary. This was formally expressed in the collective agreement. First introduced in clerical workplaces in the mid-1920s, collective bargaining soon turned into a model of labor relations for the rest of labor organized by the Histadrut. It first emerged in employment contracts in Zionist national institutions, later

so Kupferberg, "Bitu'ach Ha-Pakid - Tsav Ha-Sha'a [Insuring the Clerk - the Need of the Hour]", in Histadrut Ha-Pekidim, Alon Ha-Va'ad Ha-Merkazi, 8 (July 1934), p. 3. See also Frenkel, Idiolog' iot Te' us Be-Falestina-Ai, pp. 99-101.

37 Histadrut Ha-Pekidim, Din Ve-Chesbon [Report of the Clerks' Union] (August 1929. November 1931); A. Argov, "Al Chilufei Pekidim [On Exchanging Clerks]", Pintas, 2 (October 1935), pp. 23-25. See also the Clerks' Union correspondence with the Jewish Agency in Histadrut Ha-Pekidim, Din Ve-Cheshbon La.Ve'ida Ha-Revi'it Shel HaHistadrut Ha-Klalit [Union of Clerks' Report to the Histadrut Fourth General Convention] (1933); N. Meltser, "Me-Saviv Le-Ba'aiat Ha-Ye'ul Ba-Pekidut [On the Problem of Making Clerical Work More Efficient]". Shurot, 169 (January 1956), p. 6. 
spreading to the institutions of the Labor Movement and its holding companies; and from there, though in a very slow and limited manner, to the private sector. ${ }^{58}$

The collective agreement was presented both as preventing labor disputes and as a sign of modernization. As one activist of the Clerks' Union argued as early as 1929 :

We must point out that determining relations between the administration [of Zionist institutions] and the clerks on the basis of collective agreement not only improves relations between them and greater productivity in work, but also introduces healthy principles in the administration of the public economy. ${ }^{39}$

Moreover, the agreements included workers' demand that management should consult with clerks in questions concerning rationalization. The latter, usually entailed by redundancies, was depicted as the clerks' contribution to the enterprise in exchange for job security, and to the economy at large.

Bargaining, productivity and conflict prevention were closely connected, as was argued during the 1948 war:

This goal stood in front of our eyes in all our doings, that a written labor contract, that details item by item the rights and obligations of the worker, assures proper relations between employer and worker, integrates the community of workers covered by the contract, increases work productivity, for it decreases to the utmost friction zones. The labor contract - is an agreement between equal sides, each [...] interested in the existence of the enterprise and its economic advance. ${ }^{60}$

In the context of nation-building both sides were expected to compromise for:

There is no other starting point than the fateful and unconnected link between capital and labor, and between employer and worker, a link that no partial and obstinate tendency and no calculated interests can resist, neither theoretically nor practically. ${ }^{6 !}$

St Resolutions of the National Convention of the Clerks' Union, in Choveret Le-Inianei Ha-Pekidim (1929), pp. 32-35. The largest collective agreements were signed between the Clerks' Union and the Jewish Agency for the years 1934-1937, for which see Histadrut Ha-Pekidim, Alon Ha-Va'ad Ha-Merkazi, 7 (June 1934), pp. 4-5. Between the beginning of 1933 and summer 1934 at least ten complex collective agreements were finalized and others were under negotiation; see Histadrut Ha-Pekidim, Alon Ha-Va'ad Ha-Merkazi, 8 (July 1934), p. 2. By April 193723 collective agreements were signed, 8 in public offices, 5 in banks, 5 in commercial companies, and 5 in local committees. See the chapter on collective agreements in Report of the Clerks' Union, Pinkas, 13-14 (May 1937), pp. 717. For later developments see Glazer, "Ha-Ta'asia U-Pekide-ha", pp. 2-3.

${ }^{99}$ Gavrielli, "Ha-Politika Ha-Ta'arifit shel Histadrut Ha-Pekidim", p. 17. See also T. Cohen, "Heskemei Avoda Collectivi'im [Collective Agreements]", Shurot, 117/118 (September-October 1951), pp. 16-17.

\$ Achiluv, "Pekidei Ha-Ta'asia Ve-Hamedina Ha-Yehudit", pp. 4-5.

"1 L. Bendix, "Choze Ha-Avoda Ve-Erko La-Oved Ha-Ivri [The Labor Contract and its Value for the Jewish Laborer]", Shurot, 3 (October 1938), p. 8. 
The collective agreement, and the consequent promise of administrative productivity, artificially limited the power of employers, as was reflected in the conflict over conditions of clerking in Zionist institutions during the 1920 s and the 1930s. In many cases the agreement was presented as beneficent to national institutions, so much in need of deferent clerks. "The employers should be explained", argued one organizer of commercial clerks in 1930,

That ordered working hours and honorable relations between worker and employer are not "Bolshevism", but a trustworthy guarantee of purposeful and productive work; that the unionized and conscious clerk is also the good and talented clerk capable of executing his task because of his recognition of the responsibility laid upon him; that fair wages for the clerk is not an unproductive cost but enables the clerk to dedicate himself to work and specialize in it for his benefit, and the benefit of the enterprise. ${ }^{62}$

For private employers, in banking for example, the clerks offered collective bargaining as a necessary economic means to lessen, through coalescence of interest, the impact of military insecurity on business. Against this background the clerks argued that their campaign to professionalize clerical work, and to close their ranks, were in the interest of their employers. On the other hand, through the commitment to increase efficiency and productivity, and by adhering to a formal system of bargaining, the agreement also restrained potentially militant office workers. The clerks boasted that this restraint served the Labor Movement as a whole; any militancy could aggravate unemployment, and abstention from conflict enabled labor to lead the national integration of the Yishuv. For the clerks the effectiveness of the politics of productivity was in that it proved, even legitimized, the sincerity of their quest and struggle for prestige. The rhetorics of status and prestige were seen here to have very practical manifestations. ${ }^{63}$

The third expression of the exchange aspect of the clerks' construction of productivity, that of worker participation and joint consultation, became topical in the second half of the 1940s. Cross-strata cooperation in the

62 Ben-Ze'ev, "Pekidei Ha-Misradim U-Batei Ha-Mischar [Office Clerks and Commercial Establishments]", Pinkas, 2 (September 1930), p. 34.

${ }^{63}$ D. Cohen, Secretary of Mo'etset Poalei Cheifa (Haifa Labor Council), to Histadrut HaOvdim Be-Misradim [Union of Office Workers, namely the Clerks' Union], 4 January 1923, LA/236-1-79; Histadrut Ha-Pekidim, Din Ve-Heshbon La-Ve'ida Ha-Artsit Shel Histadrut Ha-Pekidim Ha-Ovdim Be-Misradim U.Bevatei Mischar Beretz Israel [Report of the Clerks' Union to the National Convention of the Union], 9-12 March 1927 (Jerusalem, 1927); Din Ve-Cheshbon La-Ve' ida Ha-Shlishit [Histadrut Report to its Third General Convention], 1927, pp. 48-59; A. Globmann, "Likrat Chukat Ha-Avoda [Towards Work Agreement]", Pinkas, 2 (September 1930), pp. 3-5; Editorial, "Be-lkvot Ha-Yamim [Following the Days]", Shurot, 4 (December 1938), p. 1; Editorial, "Be-Ikvot Ha-Yamim [Following the Days]", Shurot, 9/10 (December 1939), p. 1; Histadrut Ha-Pekidim, Din VeCheshbon La-Ve'ida Ha-Chamisihit [Clerks' Union Report to its Fifth National Convention], 1933-1941. 
urban sector originated in the thought and practice of cooperatives experimented with between the two world wars and also in the principles of collective bargaining molded during the same period. However, it was only at the emergence of the Jewish industrial clerk and of productivity joint councils in industry during the boom period of the Second World War that productivity and efficiency, so popularized by collective bargaining in the public sector, came to hold a central place in workers' relations with management. Industrial clerks became key figures in the first joint councils created in some of Haifa's Histadrut-owned industries. Later, at the onset of the "productivity-craze", clerks advanced their own joint councils in public offices, municipal organs and Histadrut health administration. ${ }^{64}$

Industrial and administrative productivity was the councils' raison d'être, and in fact their politics should be seen as the continuation of collective bargaining with other means. This became clear in 1949 when, following the Haifa four-year experience, the Histadrut decided to adopt the production councils as its official policy, and implement it throughout the economy. Focusing on productivity, efficiency and rationalization the councils meant to create a communication route between workers and management. Administrative Taylorite efficiency and increased clerical output were bartered for the employers' consent to consult with clerks and allow them a certain share in management. ${ }^{65}$

"Concretely [the idea] materialized in the proposal to set up a joint committee", explained one writer,

comprised of representatives of chief workers and of the work management, jointly discussing the opportunities of getting jobs and their executions, new products, [. . . ] improvement of current products, their cheapening by maximum mechanization and automation, increasing output and productivity [...] Productivity

4. S. Ziedenbank, "Al Va'adot Ha-Yetsur [On the Production Councils]", Hapoel Hatsair, 26 July 1945; Y. Dochan, "Va'adot Ha-Yetsur U.Perion Ha-Avoda [The Production Councils and Labor Productivity]", Shurot, 95/9 (October-November 1949), pp. 12-14; A. Khushi, "Ha-Poel Ve-Ha-Meshek: Tots'ote-ha Shel Shitat Ha-Premi'ot [The Worker and the Economy: The Consequences of the Bonus System]", Ha-Dor, 23 December 1949; Z. Barash, "Pekidei Ha-Ta'asia U-Moatsot Ha-Yetsur [Industrial Clerks and Productivity Councils]", Shurot, 98 (January 1950), pp. 12-13; A. Heller, "Moatsot Yitsur Ba-Ta'asia U-Ba-Sherutim [Productivity Councils in Industry and Services", Alei Sadan (October 1950), pp. 20-22; M. Mokasei, "Moe'etset Avoda Be-Kupat Cholim (Work Council in the Histadrut Sick-Fund]", Shurot, 122 (February 1952), p. 9; Ma'asim: Ha-Histadrut BeCheifa Ba-Shanin 1945-1953 [Deeds: The Histadrut In Haifa during 1945-1953] (Haifa, 1953); U. Heller, Moatsot Yitsur Ba-Ta'asia [Production Councils in Industry] (Tel Aviv, 1954); A.L. Globerson, Hiva'atsut Meshutefet Ba-Ta'asia Ha-Israelit [Joint Consultation in Israeli Industry] (Tel Aviv, 1955).

os "Ha-Igud Ha-Miktsoi Ve-Ha-Medina", an interview with M. Brantental, Ha-Dor, 2 September 1949; M. Tavor, "Le-Hagdil Ha-Tefuka, Le-Harim Perion Ha-Avoda, Le-Horid et Mechirei Ha-Totseret [To Raise Output, Increase Productivity and Decrease Output Prices]", Ha-Dor, 4 September 1949; Levi, "Ha-Pakid Ha-Meurgan Be-Medinat lsrael", pp. 4-5. 
increase does not mean greater workers' physical effort, but additional improvement of the machine, better arrangements, more suitable building, improved working conditions, better salaries. In short: to make it easier for the worker by proper arrangements, the lift up of his spirits by better salary and conditions. Both these will raise output and enhance production. ${ }^{66}$

The councils' concem with productivity and efficiency was handled in national terms. They were supposed to cheapen local products, enhance their international competitiveness, enlarge industrial production and thus facilitate immigrant absorption. Rationalization of production meant further mechanization as well as further training of the workers. "Clerks in industry are an integral part of the whole group of workers of the enterprise," argued one writer:

The clerk too must [...] lend his contribution to [raising output and increasing production]. Without the active participation of the clerk in the general effort we will not be able to lift this load. The operation capacity of an industrial plant is not expressed in increasing production by the machine. In order to increase productivity and cheapen the products' prices a good organization, work planning, cutting down costs, efficient service and full and perfect co-ordination of all the enterprise's functions are necessary. ${ }^{67}$

The democratic nature of the councils was closely connected to workersmanagement cooperation; not as a manipulative and vulgar Taylorism separating between clerical knowledge and administrative execution, but on the contrary in its integrative value; for,

Through production councils the worker is given the opportunity to express his opinion and initiate his enterprise in matters concerning the work order in the industrial plant and to cooperate in finding ways to raise the output and to increase the productivity of work and production. ${ }^{68}$

66 Ziedenbank, "Al Va'adot Ha-Yetsur". See also A. Becker, "Ha-Oved Im Kom HaMedina [The Worker at the Establishment of the State]" (1951), in idem, Ha-Oved BeIsrael [The Worker in Israel] (Tel-Aviv, 1970), pp. 36-40. For British background from which some of these ideas were borrowed see J. Hinton, Shop Floor Citizens: Engineering Democracy in 1940s Britain (Aldershot, 1994).

${ }^{67}$ Z. Barash, "Chativat Pekidei Ha-Ta'asia U-Bea'iot-eha [The Section of Industrial Clerks and its Problems]", Shurot, 123 (March 1952), p. 9. See also Mokasei, "Moe'tset Avoda Be-Kupat Cholim", p. 9; Y. Streit, "Mo'atsot Avoda Meshutafot Be-Pekidut (Joint Work Councils in Clerical Work]", Shurot, 134 (February 1954), p. 7.

6s A. Becker, "Ba-Ma'aracha Ha-Kalkalit [In the Economic Battle]", Hapoel Hatsair, 18 October 1949. Despite initial opposition of the industrialists, by January 195050 councils were established in industry: 28 in the private sector, 19 in the Histadrut enterprises and 3 in the public sector. They served 11,500 workers, 30 per cent in the private sector, 40 per cent in the Histadrut, and 30 per cent in the public sector. See "Moatsot Ha-Yetsur", in Ha-Histadnut Ha-Klalit, Be-Shnot Ha-Sheloshim: Sekirot Ve-Sikumim, 1921-1951 [In the Thirtieth Year: Surveys and Summaries] (Tel Aviv, 1951), pp. 324-326. For comparison see Y. Shenhav, Mechonat Ha-Irgun: Chakira Bikortit Be-Yesodot Torat Ha-Nihul [The Organization Machine: A Critical Inquiry into the Foundations of Management Theory] (Jerusalem and Tel Aviv, 1995), p. 198. 
Similar to collective bargaining, the new point of contact worked to restrain both employers and workers:

How is it possible to draw plans of productivity increase in industry without the clerk and the technician, those that manage production and supervise it [...] In all those countries where production councils are already operating, clerks are represented as are workers and employers, for the fate of industry is in the hands of all these three factors [...] Only cooperation, agreement and mutual understanding between the employers, the clerks and the workers will improve production methods and product quality.

In this consensual productivist politics the clerks were presented as a vital factor, keeping a balance between employers and workers:

On the one hand they must restrain the employer's appetite who would like to burden the workers, through the production councils, with more workloads far beyond the worker's ability. On the other hand they should convince the workers that enhancement of production is not only a matter for the employer but no less than that their own. The clerk in the production council should be flexible and careful, so that the workers will not see in him an enemy siding with the employer against them. ${ }^{69}$

\section{PRODUCTIVITY POLITICIZED}

This concem with productivity and social utility had wider political effects. As the self- and social-assessments of productivity in Palestine's Jewish society were subjective, politically-oriented and normative, it was quite natural that the concept of productivity, routinely related to in the context of work, should become laden with larger cultural and political meanings. However, implied in the clerks' reproductive and transformative discourse was a deeper layer which reflected a mechanism of social coalescence and collective-making in town society which were vitally instrumental in the Zionist state-building process. ${ }^{70}$

This mechanism should be understood in the light of the centrality of the image of productivity in the complex relationship between the Jewish Labor Movement, and the large social bases of the Jewish lower middle class in the Diaspora and would-be future immigrants to Palestine. Since the early 1920s the Movement was in an ambivalent position between its class ideology and the actual small size of the Jewish class of workers in

69 Editorial, "Vadot Ha-Yetsur Ve-Tsibur Ha-Pekidim [Production Committees and the Cletks' Community]", Shurot, 93 (September 1949), pp. 10-11. See also Ha-Ve'ida Ha. Shevi' it Shel Ha.Histadrut [The Histadrut Seventh General Convention] (September 1949); Dochan, "Vadot Ha-Yetsur U.Perion Ha-Avoda", pp. 12-14; Levi, "Ha-Pakid HaMeurgan Be-Medinat Israel", pp. 4-5; Ha-Kinus Ha-Artzi Shel Va'adei Poalim be-Mifalei Ha-Charoshet Ha-Histadruti' 'im [The National Convention of Workers' Committees in Histadrut Industrial Enterprises], II-12 January 1946, Ba-Histadrut (April 1946); M.G., "Lama Ne'edar Mekomo Shel Ha-Pakid", p. 17.

${ }^{70}$ For background see Horowitz and Lissak, The Origins of the Israeli Polity, ch. 9. 
Palestine. The notion of creating a working class, and the urgent need to operationalize this creation, accompanied the evolution of the Labor Movement from very early on. And it entailed not only political and social cooperation, on national grounds, with the Jewish middle strata (abroad and in Palestine), on which labor depended, but also the obfuscation of class ideology and restraint of militants. The process was invigorated by the waves of mass Jewish immigration from Eastem and Central Europe in 1924-1926 and 1932-1934, which invigorated a differentiation of the Histadrut's social bases, and a consequent weakening of its social cohesion. Moreover, the restraining of the political left, which attempted to advance radical and more militant concepts of class formation and social conflict, became an issue of survival for the Labor Movement, a political banner directed at various sorts of workers inside the Movement, and to other social groups outside the Histadrut."

The clerks' modemist diversification of productivity served this goal very well: if clerks were productive as any other labor, then the meaning of the productivization of the Diaspora social bases of the Yishuv could be regarded as malleable and flexible; thus allowing those who were not necessarily hand-workers (Ovdei Kapai' im) to be considered part of labor. The Labor Movement could thus be transformed into a large framework, a sort of umbrella organization, gathering ordinary workers, clerks, technicians, commercial entrepreneurs, independent artisans, scientists, all sorts of professionals and even employed managers. Presented by their ideologues in a politicized manner, the clerks could thus become mediators between the Labor Movement and its future social base, and a bridge between organized and non-organized workers. In these images of mediation and political arbitration, of constructing a larger concept of the labor community, the clerks were placed as the ideological and actual force that made the consequent transformation of labor possible. By legitimating wider and more flexible notions of productivity and social utility, the clerks' ideologues meant to allow the non-class character of labor and the opening of its ranks to all social strata. White-collar workers thus became the social basis, even precursors of the necessary transformation of labor during state-building, coined by David Ben-Gurion, the leader of the Labor Movement, as the change "From Class to Nation [Me-Ma'amad Le$A m]^{\prime \prime} \cdot{ }^{72}$

${ }^{71}$ M. Lissak, "Strategies of Class Formation: The Case of the Labour Movement in the Jewish Community of Palestine: 1918-1948", in E. Cohen, M. Lissak and U. Almagor (eds), Comparative Social Dynamics (London, 1985), pp. 245-261; D. De Vries, "Proletarianization and National Segregation: Haifa in the 1920s", Middle Eastern Studies, 30, 4 (October 1994), pp. 860-882; Y. Gelber, " 'Ha-Yehudi He-Chadash' Ve-Itsuvo Ba-Chevra Ha-Israelit [The 'New Jew' and Its Molding in Israeli Society]", in I. Gutman (ed.), Terurot Yesod Ba-Am Ha-Yehudi Be'lkvot Ha-Sho'a [Major Changes Within the Jewish People in the Wake of the Holocaust] (Jerusalem, 1996), pp. 425-442.

7 D. Ben-Gurion, "Ha-Yi'ud Ha-Leumi Shel Ma'amad Ha-Poalim [The National Destiny of the Working Class]", Kuntres, 210 (24 Adar 5685) [20 March 1925]; M.A. Perlmutter, 
The powerful activists of the dominant Palestine Workers' Party [Mapai] and of the unions in the Histadrut were interested in the clerks becoming such social mediators. As the clerks were placed in key positions in the institutions of the Zionist project and in various privatelyowned establishments, they were close to employers, and to the Jewish "capital-owning" strata in general; but more so to the incoming immigrants whose first contacts were with the bureaucrats of the absorption system. Like engineers, physicians or teachers, who were also called in to join the Histadrut, the status ambiguity of white-collar workers became useful to the Labor Movement, so much in need of cooperation with other strata. Thus, the relationships between the clerks and the movement served as a model for labor's relations with the rest of Jewish society. In admitting the notion of the productive and socially useful clerk the Labor Movement could widen its social base, avoid conflict with the Jewish lower middle class, and find inroads to sources of employment and capital which preferred a weak class definition of labor. It could then present itself as an integrative force so vital in the formation of the state. ${ }^{73}$

The social mechanism discerned in the reproduction and transformation of the notions of productivity, also manifested itself in the exchange features of labor relations. Indeed the spread and institutionalization of collective bargaining and joint consultation should be counted among the points of contacts emerging in Yishuv politics which mitigated social tensions and obfuscated differences of class and status. Through bargaining and consultation the bypassing of labor conflicts made productivity, and its various usages, crucial to social peace. After all it was in these arenas where the particular social-democratic version of Israeli corporatism evolved. ${ }^{74}$

Clerks, placed as they were in potential areas of labor disputes - in national institutions, in the Histadrut and in the private sector - were key figures in this process of social arbitration between employers and employees. By borrowing and enlarging the notion of labor productivity they turned the consensus in Zionist society - on the pioneer, the collective of pioneers and hand-workers and the national utility of constructive work - into a usable machinery of labor restraint and social compromise. In this sense the two sets of clerks' relations, with the Labor Movement

"Ha-Ein Ha-Pekidut Zekuka Le-Chalutsim? [Does Not Clerking Need Pioneers?]", Shurot, 42 (September 1944), p. 10; Be-Mivchan Ha-Ma'aseh, 1949.

73 Y. Norman, "Ha-Intelligentsia Ha-Ovedet [The Labor Intelligentsia]", Ha'Adama, 3 (1 Kislev 5680) [23 November 1919], pp. 327-333; D. Giladi, "Yozma Pratit, Hon Le'umi Ve-Gibush Politi Shel Ha-Yamin [Private Initiative, National Capital and the Political Integration of the Right]", in S.N. Eisenstadt et al. (eds), Ha-Mivneh Ha-Chevrati Shel Israel [Israel's Social Structure] (Jerusalem, 1969), pp. 86-98; J. Gorni, Achdut Ha-Avoda 1919-1930 [The Union of Labor] (Tel Aviv, 1973), ch. 3; A. Shapira, "Demuto Shel 'Ha-Yehudi He-Chadash' Ba-Chevra Ha-Yeshuvit [The Image of the 'New Jew' in Jewish Society in Palestine]", in Gutman, Temurot Yesod Ba-Am Ha-Yeludi, pp. 411-423.

"M. Shalev, Labour and the Political Economy' in /srael (Oxford, 1992), introduction. For comparison see Carew, Labour Under the Marshall Plan, chs 9-12. 
and with employers, were closely connected. In both the language of productivity was justified as a means of attenuation of friction, between labor and other popular strata, and between labor and the employers. The advancing of group material and cultural interests on the one hand, and the imbuing of productivity with social-political meanings on the other, became inseparable.

Was this mechanism of restraint a from-below strategy of the clerks' ideologues, or alternatively a manipulation from above, by the leaders of the Labor Movement and other political and economic elites in the Yishuv, or perhaps a combination of the two? It can be presumed that further research will show that activity stemmed from both directions. The clerks' ideologues sincerely advanced the interests of their rank and file - be they economic or political, nationally or socially oriented. At the same time they became, often in a formal manner, socializing agents of political elites. The latter were advancing a national project, and the logic of their domination determined that the moderation of potential points of conflict was imperative to this project. In the clerks - struggling as they were to bridge the gap between their improving status and low prestige - they found loyal and obedient allies. ${ }^{75}$

\section{CONCLUSION}

It is here that the politics of status and labor relations merged, and that the explanation of the clerks' discourse of productivity was borne out. The clerks claimed prestige as the prominent force in making Palestine a modern country with an efficient economy. Their output was as material as any other, and no less vital than the products accrued in other laboring sectors. In a society so preoccupied with increasing its economic capacity, immigrant absorption, demographic advantage over Arabs, settlement and the construction of means purported to tame a growing and fragmented urban society - these values, and their appropriation, were valuable weapons in status struggles. The enlargement of the notion of productivity meant a sort of rewriting of the dominant Zionist text, in a manner that allowed the social significance of town society, the brain-worker and abstract produce. The clerks not only tried to appropriate physiocratic, pioneering and constructive values and apply them to office environment, but claimed a distinctive position. They did not just intend to mold an alternative or a counter-discourse, nor to challenge the dominant one; but to transform it by stressing its forward-looking vision, and situate the clerks as essential and indispensable agents of technocratic modernity and professional state-building. In this process of reformulating accepted notions productivity was redefined.

73 Compare with a similar role related to teachers in R. Firrer, Sochnim Shel Ha-Chinuch Ha-Tsioni [Agents of Zionist Education] (Tel Aviv, 1985). 
Furthermore, the wholeharted mobilization of office workers to the cause of productivity, as was manifested in the variety of their practices, acted as a self-disciplining, or self-regimentation, to the Zionist state collective. This normative statist collectivization, building up gradually until the first years of the state's existence, was reflected in collective mental self-harnessing, and in matching one's images of the clerical occupation to a larger set of national Zionist and Labor-Zionist values. Through adherence to productivity the clerks reflected their socialization, their normative regimentation, not just to Zionist state-building, but also to the workplace and the employer. Loyalty to office work, to its improvement and output, were handled in Zionist terms, thus turning the language of work into a cultural resource of national imagery, political manipulation and, significantly, of incipient language managerial control. The notion of the office as a clerical collective, becoming productive through team and collegial work, was closely connected with one's social and national roles in statebuilding, but also with the esprit de corps of the workplace.

In this way the usage of productivity, its conceptual enlargement and its utilization in intra-labor and labor-employers relations, entailed a relational dimension that was later translated into work control. Appropriating dominant notions of productivity and social utility endowed the clerks' ideologues with the aura of propagators and agents of the Zionist collective and its ideology. In conjuring an enlarged version of productivity and placing it in the midst of the politics of arbitration, they also constructed the image of clerks as trustworthy and reliable members of the collective, loyal practitioners and performers of the Zionist project, and servants of economic enterprise.

Through the outlining of the ideal clerk, and the making of the proper work environment conducive to rationalized economics and efficient clerking, a series of values were transmitted: collectivism, nationalpolitical loyalty, adherence to labor, restraint of potential militancy and, last but not least, conformism. The efforts to achieve status and prestige, and to gain legitimization through improved power-positions and arbitration, was a mechanism of collectivizing the clerks, both in the national sense and the corporate managerial one. The discourse of status, power, legitimacy and interests was chequered with the shackling features of a conformist, subdued, obedient and conservative worker - features that later would come to characterize the labor terminology of Israeli management and office work culture. ${ }^{76}$

${ }^{76}$ See Din Ve-Cheshbon Shel Va'ad Ha-Senif Shel Histadrut Ha-Pekidim Be-Yerushala' im [Report of the Jerusalem Branch Committee of the Clerks' Union], 1943-1947 (Jerusalem, 1947); B. Aktzin, Ikarei Ha-Minhal Ha-Tsiburi [Principles of Public Administration] (Jerusalem, 1952); Din Ve.Cheshbon Shel Histadrut Ha-Pelidim La-Telufa Yanuar 1950. Merz 1952 [Clerks' Union Report for the Period January 1950-March 1952] (Tel Aviv, 1952); A. Tartakover, "Chevra, Medinah Ve-Chinuch Pekidim [Society, State and Clerks" Education]", Ha-Minhal, 13 (Spring 1953), pp. 6-8; G. Uriel, Minhal Misradi [Office 
The language of trustworthiness was of course part of the political socialization of the mass of urban clerks. However, the willful regimentation of the clerks to the collectivity of the Jewish settlement also served to coalesce, through the building of a powerful trade union, the varied forces of the clerical sector, and to forestall potential opposition among them to the authority of employers or to that of the Labor Movement. Internal union democracy, the means to express militancy, was often curbed for the sake of economic gains and union power.

Thus, productivity and social utility, in themselves socially-constructed tools of status elevation and political power, could actually turn into restraining imagery, a conforming language and a conservative discourse. Understandably it was a natural corollary of the quest to do away with marginality, to be included in the national collective, and to be counted as worthy mediators in a state-building society. But it was perceived by the ideologues of the Clerks' Union and the Labor Movement in a wider scope as constructive and vital conservatism, an essential from-below consent to normative control at the workplace and in society, a selfdisciplinary behavior of town-dwellers, otherwise lacking the frameworks of collectivity and integration. The clerks' self-image as modemists, valuable and productive technocrats, and essential contributors to the efficient technological vision of the Zionist project, went hand in hand with this conservatism, with the obfuscation of conflict and with conformity. In the conditions of intensive institutionalization of the state, and of the evolving corporatist nature of its social order, this mixture had had far-reaching consequences that deserve further scholarly attention. ${ }^{77}$

Administration] (Jerusalem, 1959); A. Globerson, Nihul Chever Ovdim: Ikarim [Managing A Group of Workers: Principles] (Tel Aviv, 1959). See also G. Kunda, Engineering Culture: Control and Commitment in a High-Tech Corporation (Philadelphia, 1992), pp. 1113, 160-162.

$n$ Compare with S. Carmi and H. Rosenfeld, "The Rise of Militaristic Nationalism in Israel", International Journal of Politics, Culture and Society, 3, 1 (Fall 1989), pp. 5-49. 